Rui-Ming Shi, MD, $\mathrm{PhD*}$

Tomoko Kobayashi, MD, $\mathrm{PhD*}$

Atsuo Kikuchi, MD, PhD

Ryo Sato, MD

Mitsugu Uematsu, MD, $\mathrm{PhD}$

Kumiko An

Shigeo Kure, MD, PhD

Neurol Genet

2017;3:e133; doi: 10.1212/ NXG.0000000000000133

Supplemental data at Neurology.org/ng

\section{PHENYTOIN-RESPONSIVE EPILEPTIC \\ ENCEPHALOPATHY WITH A TANDEM \\ DUPLICATION INVOLVING FGF12 \\ OPEN}

Nonsecreting fibroblast growth factors (FGFs), which are sodium channel-binding proteins, have recently been associated with neurodevelopmental disorders, ${ }^{1,2}$ similar to some voltage-gated sodium channel subunits. Recently, a de novo mutation in FGF12 (p. R52H) was reported in a pair of siblings with epileptic encephalopathies. ${ }^{3}$ The affected siblings developed severe seizures within 1 month of age, and their seizures were refractory to multiple antiepileptic drugs. This mutation has a gain-of-function effect on sodium channel gating, which might lead to increased neuronal excitability. Here, we report another case of FGF12-related epileptic encephalopathy. In contrast to the previous report, the phenotype in our patient was relatively mild. Of note, his seizures responded to phenytoin, a sodium channel blocker, similar to epileptic encephalopathy associated with $S C N 2 A^{4}$ and $S C N 8 A,{ }^{5}$ encoding voltagegated sodium channel subunits.

The boy was born as the first child of a nonconsanguineous Japanese couple at term after an uncomplicated pregnancy with a birth weight of $3,100 \mathrm{~g}(-0.5$ SD), a birth height of $48.2 \mathrm{~cm}(-1.2 \mathrm{SD})$, and a birth head circumference of $33.4 \mathrm{~cm}(-0.4 \mathrm{SD})$. The patient had been healthy with no seizures before 3 years of age. Fever due to viral infection triggered his first seizure, followed by daily seizures without fever. Three types of seizures, including tonic-clonic seizures, brief tonic seizures with vocalization, and complex partial seizures with repeated blinking, were observed. An EEG showed severe suppression of background activity with paroxysmal bursts (figure e-1B at Neurology.org/ng). His seizures were refractory to multiple antiepileptic drugs, including phenobarbital, clobazam, valproic acid, and potassium bromide, but responded to phenytoin add-on, which was started after 2 years of the onset of seizures. His seizures were completely controlled with phenytoin levels between 20 and $35 \mu \mathrm{g} / \mathrm{mL}$ (figure 1B). Brain MRI showed mild cerebral and cerebellar atrophy at the age of 8 years (figure 1A). Just after the onset of seizures, his development was halted, and he developed ataxia and aphasia. These clinical symptoms were gradually exacerbated, although his seizures have been suppressed. He can walk, although ataxic, and take a liquid diet himself when his seizures are suppressed; when his seizures are not suppressed, he becomes bedridden with severe feeding difficulties due to dysphagia necessitating tube feeding and presents with sleep disorder and dyspnea. At the last follow-up, he showed profound intellectual disability. He had a long face, bilateral epicanthal folds, longslitted eyes, a broad nose, straight and broad eyebrows, and ptosis (figure e-1B).

Array comparative genome hybridization revealed a $0.58-\mathrm{Mb}$ gain, $\operatorname{arr}[\mathrm{hg} 19]$ 3q28q29 (191876978_192454675) $\times 1$ (figure 1C). Analysis of the parents confirmed that this 3-copy gain occurred de novo. The copy-number gain was confirmed by fluorescence in situ hybridization and genomic quantitative PCR analysis (figure e-2). Around the edges of the copy-number variation $(\mathrm{CNV})$ gain, there were $2 \mathrm{~L} 1$ family long interspersed nuclear elements (LINEs) (L1PA2), suggesting that a tandem duplication occurred via these LINEs. In CNV-specific PCR, a positive PCR was obtained only from the patient's genomic DNA, which therefore confirmed both the existence of the duplication and its tandem arrangement (figure 1D). Sequencing of the PCR product determined the breakpoint regions with a 48-bp overlap (figure 1E). Target sequencing of epileptic encephalopathy-related genes did not detect any candidate mutations (appendix e-1).

Using CNV-specific real-time PCR, aberrant transcripts were detected only in the patient's hair follicle (figure e-3). Sequencing of the PCR products revealed aberrant transcripts with or without an inserted aberrant exon. Complementary DNA analysis showed biallelic expression of FGF12 with abnormal transcripts (figure e-3). No difference in the expression of FGF12 between the complementary DNAs of the patient and controls was detected (data not shown).

Because we did not investigate the aberrant protein expression from the duplicated allele, it remains unclear whether the phenotype of our patient occurred because of gain-of-function, haploinsufficiency, or dominant-negative effects of FGF12. It is possible that the CNV has gain-of-function effects, 

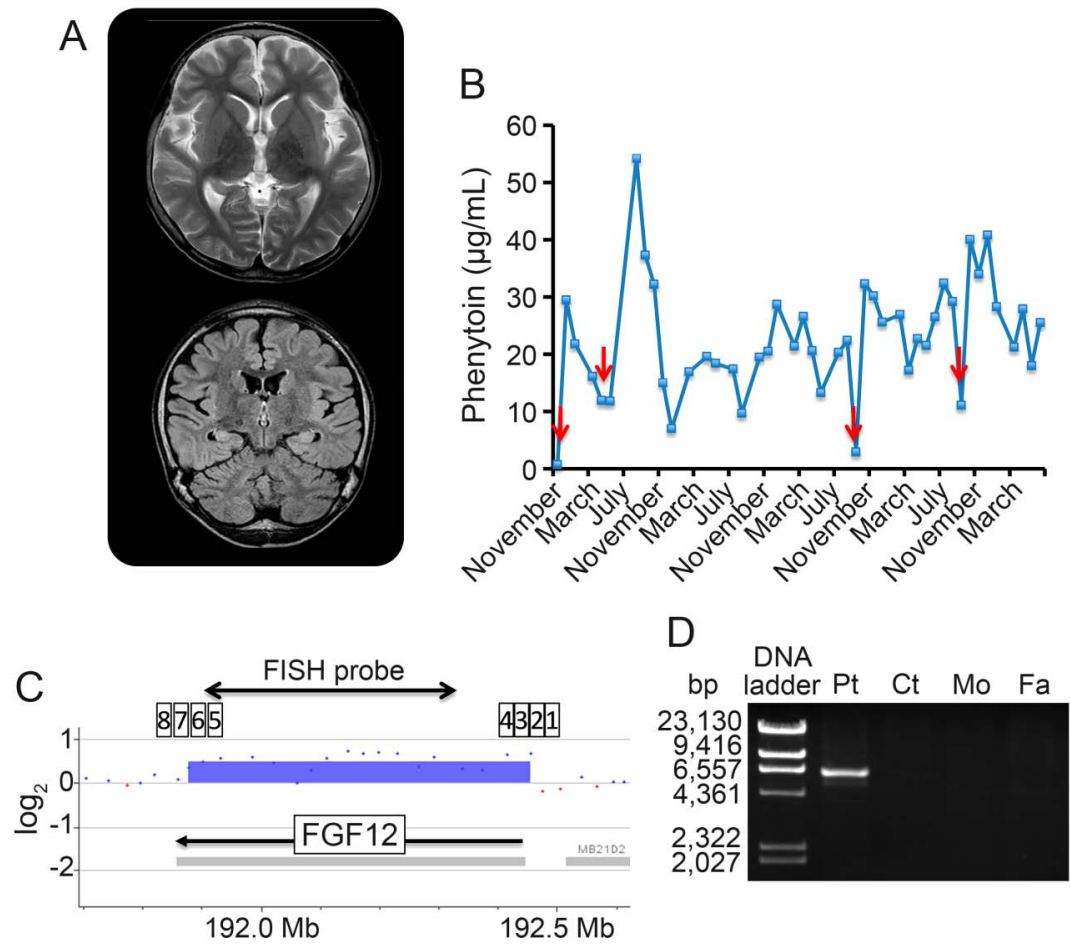

$E$
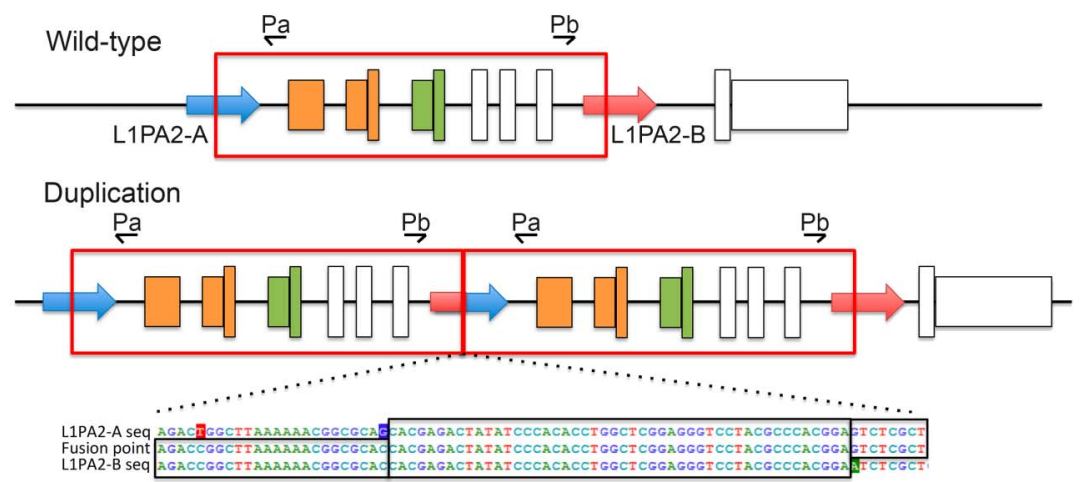

48 bp overlap

(A) Axial T2-weighted image (top) and fluid-attenuated inversion recovery (bottom) of the brain at age 8 years showed mild cerebral and cerebellar atrophy without signs of associated focal cortical dysplasia or postischemic injury. (B) Phenytoin levels of the patient. Red arrows indicate hospital admissions for increased seizure frequency. (C-E) Genomic analysis revealed a tandem duplication, involving FGF12, between 2 long interspersed nuclear elements (LINEs). (C) Array comparative genome hybridization showed a 0.6-Mb gain, which contains nearly the entire FGF12 gene. A double-headed arrow indicates the position of the fluorescence in situ hybridization (FISH) probe for FGF12 (see also figure e-2A). The numbers in boxes indicate the primer positions for quantitative PCR analysis (see also figure e-2B). (D) Copy-number variation (CNV)specific PCR. A 6-kb junction amplicon was generated from the patient but not from the control and his parents. (E) Schematic map showing the wild-type and duplication alleles. Boxes indicate exons of FGF12. Yellow, green, and white boxes indicate exons for FGF12 isoform 2 (NM_004113.5), FGF12 isoform 1 (NM_021032.4), and common exons, respectively. Blue and red arrows indicate LINEs. The breakpoints lie within 2 LINE L1PA2s occurring at chr3:192457003192463031 and chr3:191867105-191873117 with a 48-bp overlap. $\mathrm{Pa}, \mathrm{Pb}=$ primers for CNV-specific PCR (D). FGF = fibroblast growth factor.

similar to the previous patients. Similar to our patient, phenytoin was used also in most of the previous patients with the $\mathrm{R} 52 \mathrm{H}$ mutation in FGF12, ${ }^{6}$ suggesting that the same mechanism underlies the pathogenicity of the previous cases and our case. The aberrant proteins from the duplicated allele in our patient are predicted to have duplicated sodium channel-binding sites. ${ }^{7}$ By contrast, some in silico data indicate that haploinsufficiency of FGF12 may also be sufficient to invoke a disease phenotype. Lossof-function mutations are absent except in the last exon or isoform-specific exons in the Exome Aggregation Consortium (ExAC) database (ExAC, Cambridge, MA; URL: exac.broadinstitute.org, last 
accessed May 2016). Moreover, the haploinsufficiency score ${ }^{8}$ for FGF12 is extremely low (haploinsufficiency index 3.95\%). Our case supports the results of the previous report, ${ }^{3}$ highlighting the requirement for fine-tuning of the FGF12 dosage to maintain normal brain activity. Further functional analysis will enhance the understanding of the genotype-phenotype relationship.

This report provides further evidence for a causative gene for epileptic encephalopathy and expands the phenotypic spectrum of FGF12-related epileptic encephalopathy. We also propose the therapeutic use of sodium channel blockers for FGF12-related epileptic encephalopathy.

* These authors contributed equally to this work.

From the Department of Pediatrics (R.-M.S.), the First Affiliated Hospital of Xi'an Jiaotong University, China; Division of Genomic Medicine Support and Genetic Counseling (T.K.), Department of Education and Training, Tohoku Medical Megabank Organization (ToMMo), Tohoku University; Department of Pediatrics (R.-M.S., T.K., A.K., R.S., M.U., S.K.), Tohoku University School of Medicine; and Department of Clinical Laboratory (K.A.), Tohoku University Hospital, Sendai, Japan.

Author contributions: Rui-Ming Shi: study concept and design, acquisition of data, data analysis and interpretation, and accepts responsibility for conduct of research. Tomoko Kobayashi: acquisition of data, data analysis and interpretation, drafting manuscript, and accepts responsibility for conduct of research. Atsuo Kikuchi: study concept and design, acquisition of data, data analysis and interpretation, drafting and revising manuscript, final approval, and accepts responsibility for conduct of research. Ryo Sato, Mitsugu Uematsu, and Kumiko An: acquisition of data, data analysis and interpretation, and accept responsibility for conduct of research. Shigeo Kure: study concept and design, study supervision, data analysis and interpretation, revising manuscript, and accepts responsibility for conduct of research.

Study funding: This work was partially supported by the Initiative on Rare and Undiagnosed Diseases in Pediatrics (IRUD-P) from the Japan Agency for Medical Research and Development (to S.K.).

Disclosure: Rui-Ming Shi reports no disclosures. Tomoko Kobayashi has received research support from AMED. Atsuo Kikuchi has received research support from Novartis Pharma and JSPS
KAKENHI (JP15K19597, JP16K09983, JP16K10056, and JP25461534). Ryo Sato, Mitsugu, Kumiko An, and Shigeo Kure report no disclosures. Go to Neurology.org/ng for full disclosure forms. The Article Processing Charge was paid by the authors.

This is an open access article distributed under the terms of the Creative Commons Attribution-Non Commercial-NoDerivatives License 4.0 (CC BY-NC-ND), which permits downloading and sharing the work provided it is properly cited. The work cannot be changed in any way or used commercially without permission from the journal.

Received August 24, 2016. Accepted in final form December 20, 2016.

Correspondence to Dr. Kikuchi: akikuchi-thk@umin.ac.jp

1. Puranam RS, He XP, Yao L, et al. Disruption of Fgf13 causes synaptic excitatory-inhibitory imbalance and genetic epilepsy and febrile seizures plus. J Neurosci 2015;35: 8866-8881.

2. van Swieten JC, Brusse E, de Graaf BM, et al. A mutation in the fibroblast growth factor 14 gene is associated with autosomal dominant cerebral ataxia [corrected]. Am J Hum Genet 2003;72:191-199.

3. Siekierska A, Isrie M, Liu Y, et al. Gain-of-function FHF1 mutation causes early-onset epileptic encephalopathy with cerebellar atrophy. Neurology 2016;86:2162-2170.

4. Howell KB, McMahon JM, Carvill GL, et al. SCN2A encephalopathy: a major cause of epilepsy of infancy with migrating focal seizures. Neurology 2015;85:958-966.

5. Boerma RS, Braun KP, van den Broek MPH, et al. Remarkable phenytoin sensitivity in 4 children with SCN8A-related epilepsy: a molecular neuropharmacological approach. Neurotherapeutics 2016;13:192-197.

6. Al-Mehmadi S, Splitt M; For DDD Study group*, et al. FHF1 (FGF12) epileptic encephalopathy. Neurol Genet 2016;2:e115.

7. Goetz R, Dover K, Laezza F, et al. Crystal structure of a fibroblast growth factor homologous factor (FHF) defines a conserved surface on FHFs for binding and modulation of voltage-gated sodium channels. J Biol Chem 2009;284: 17883-17896.

8. Huang N, Lee I, Marcotte EM, Hurles ME. Characterising and predicting haploinsufficiency in the human genome. PLoS Genet 2010;6:e1001154. 


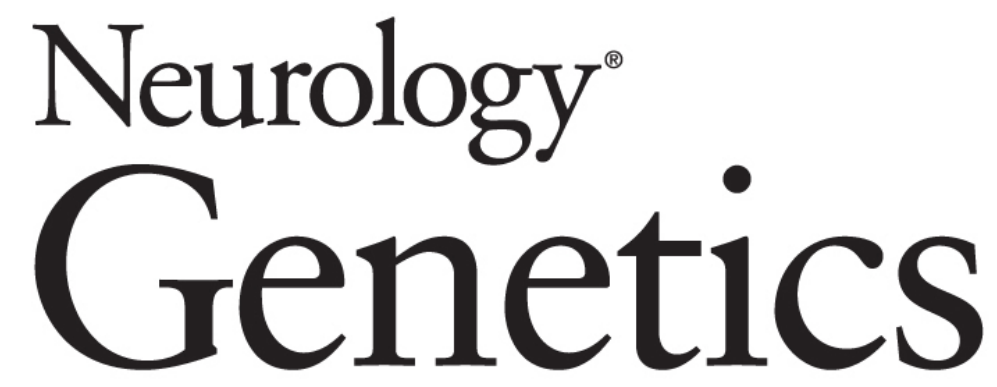

Phenytoin-responsive epileptic encephalopathy with a tandem duplication involving FGF 12

Rui-Ming Shi, Tomoko Kobayashi, Atsuo Kikuchi, et al. Neurol Genet 2017;3;

DOI 10.1212/NXG.0000000000000133

This information is current as of January 23, 2017

Neurol Genet is an official journal of the American Academy of Neurology. Published since April 2015, it is an open-access, online-only, continuous publication journal. Copyright Copyright ( 2017 The Author(s).

Published by Wolters Kluwer Health, Inc. on behalf of the American Academy of Neurology. All rights reserved. Online ISSN: 2376-7839.

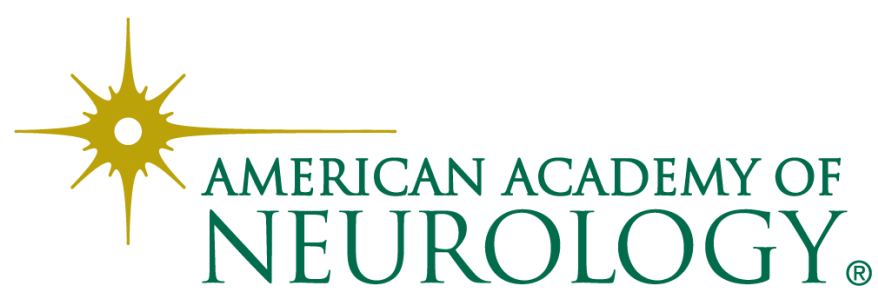




\section{Updated Information \& Services}

\section{Supplementary Material}

\section{References}

Citations

Subspecialty Collections

Permissions \& Licensing

Reprints including high resolution figures, can be found at: http://ng.neurology.org/content/3/1/e133.full.html

Supplementary material can be found at: http://ng.neurology.org/content/suppl/2017/01/23/3.1.e133.DC1

This article cites 8 articles, 3 of which you can access for free at: http://ng.neurology.org/content/3/1/e133.full.html\#\#ref-list-1

This article has been cited by 1 HighWire-hosted articles: http://ng.neurology.org/content/3/1/e133.full.html\#\#otherarticles

This article, along with others on similar topics, appears in the following collection(s):

All Epilepsy/Seizures

http://ng.neurology.org//cgi/collection/all_epilepsy_seizures

Antiepileptic drugs

http://ng.neurology.org//cgi/collection/antiepileptic_drugs

Ion channel gene defects

http://ng.neurology.org//cgi/collection/ion_channel_gene_defects

Information about reproducing this article in parts (figures,tables) or in its entirety can be found online at:

http://ng.neurology.org/misc/about.xhtml\#permissions

Information about ordering reprints can be found online:

http://ng.neurology.org/misc/addir.xhtml\#reprintsus

Neurol Genet is an official journal of the American Academy of Neurology. Published since April 2015, it is an open-access, online-only, continuous publication journal. Copyright Copyright ( 2017 The Author(s). Published by Wolters Kluwer Health, Inc. on behalf of the American Academy of Neurology. All rights reserved. Online ISSN: 2376-7839.



